\title{
The association of the fat mass and obesity-associated gene (FTO) rs9939609 polymorphism and the severe obesity in a Brazilian population
}

This article was published in the following Dove Press journal:

Diabetes, Metabolic Syndrome and Obesity: Targets and Therapy

\author{
Ana Carolina Proença \\ da Fonsecal \\ Gabriella Medeiros Abreu' \\ Verônica Marques Zembrzuski' \\ Mario Campos Junior ${ }^{\prime}$ \\ João Regis Ivar Carneiro ${ }^{2}$ \\ José Firmino Nogueira Neto ${ }^{3}$ \\ Giselda Maria Kalil Cabello' \\ Pedro Hernán Cabello ${ }^{\text {I,4 }}$ \\ 'Human Genetics Laboratory, Oswaldo \\ Cruz Institute/FIOCRUZ, Rio de Janeiro, \\ Brazil; ${ }^{2}$ Clementino Fraga Filho University \\ Hospital, Federal University of Rio de \\ Janeiro, Rio de Janeiro, Brazil; \\ ${ }^{3}$ Department of Pathology and \\ Laboratory, Rio de Janeiro State \\ University, Rio de Janeiro, Brazil; ${ }^{4}$ Human \\ Genetics Laboratory, Grande Rio \\ University, Rio de Janeiro, Brazil
}

Background: Obesity occurs due to the interaction between the genetic background and environmental factors, including an increased food intake and a sedentary lifestyle. Nowadays, it is clear that there is a specific circuit, called leptin-melanocortin pathway, which stimulates and suppresses food intake and energy expenditure. Therefore, the aim of this study was to evaluate the influence of genetic variants related to appetite regulation and energy expenditure on severe obesity susceptibility and metabolic phenotypes in a Brazilian cohort.

Material and methods: A total of 490 participants were selected (298 severely obese subjects and 192 normal-weight individuals). Genomic DNA was extracted and polymorphisms in protein related to agouti ( $A G R P$; rs5030980), ghrelin (GHRL; rs696217), neuropeptide Y (NPY; rs535870237), melanocortin 4 receptor (MC4R; rs17782313), brain-derived neurotrophic factor (BDNF; rs4074134) and fat mass and obesity-associated (FTO; rs9939609) genes were genotyped using TaqMan ${ }^{\circledR}$ probes. Demographic, anthropometric, biochemical and blood pressure parameters were obtained from the participants.

Results: Our results showed that FTO rs9939609 was associated with severe obesity susceptibility. This polymorphism was also related to body weight, body mass index (BMI), waist to weight ratio (WWR) and inverted BMI. Individuals carrying the mutant allele (A) showed higher levels of BMI as well as lower values of WWR and inverted BMI. Conclusion: This study showed that FTO rs9939609 polymorphism plays a significant role in predisposing severe obesity in a Brazilian population.

Keywords: leptin-melanocortin pathway, FTO, obesity, polymorphisms, hypothalamus

\section{Introduction}

Obesity is a serious health and economic problem in the world, affecting low-, middleand high-income countries. ${ }^{1,2}$ It is defined as an excess in body fat accumulation and can be qualitatively measured using a body mass index (BMI, BMI $\geq 30 \mathrm{~kg} / \mathrm{m}^{2}$ ). Recent data estimated that obesity has almost tripled since the $70 \mathrm{~s}$ and there were more than 650 million obese adults worldwide in 2016. ${ }^{1}$ In Brazil, $11.7 \%$ of men and $20.6 \%$ of women are obese. ${ }^{3}$ This high prevalence can be explained by environmental changes, resulting in an energy imbalance caused by excessive caloric intake and diminished physical activity. Moreover, obesity is a major risk factor for several comorbidities, including type 2 diabetes, hypertension, osteoarthritis, cardiovascular diseases and da Fonseca

Human Genetics Laboratory, Oswaldo Cruz Institute, Oswaldo Cruz Foundation (FIOCRUZ), Leônidas Deane Building, room 615, Leônidas Deane Building, room 615, Rio de Janeiro, RJ 21040-360, Brazil

Email ana_carol_pf@hotmail.com 
some cancers. ${ }^{1}$ In addition, there is evidence that higher BMI causes a proportional higher risk for these comorbidities and also higher mortality. ${ }^{4}$

Obesity is a complex phenotype influenced by genetic, psychological, behavioral, nutritional and environmental factors. ${ }^{5}$ The most common form of obesity seems not to follow a Mendelian inheritance model and is caused by an interaction of environmental factors with multiple genetic variants with minor effect. ${ }^{6}$ Within the last couple of years, genome-wide association (GWA) and whole exome studies (WES) have identified several variants associated with obesity; however, most of the genetic contribution for this disease remains unknown. ${ }^{7-11}$ Furthermore, the association between the genetic variants and obesity was replicated mainly in European and Asian cohorts, while for Latin American populations data are still scarce. ${ }^{10,12-14}$

Many of the identified obesity genes are expressed and/ or act in the central nervous system (CNS), suggesting a neuronal component in obesity susceptibility. ${ }^{8}$ There, a specific circuit, called leptin-melanocortin pathway, promotes and suppresses appetite and energy expenditure. ${ }^{15,16}$ Ghrelin (GHRL) is abundantly secreted by the stomach when the body is in restriction of food and low energy stock. This peptide binds to the ghrelin receptor and increases the expression of neuropeptide Y (NPY) and agouti-related protein (AgRP) in the orexigenic neurons. ${ }^{15,17,18}$ These neurons project from the arcuate nucleus (ARC) to the paraventricular nucleus (PVN) of the hypothalamus, where AgRP acts as antagonist of the melanocortin-4 receptor (MC4R) and NPY binds to its receptor, increasing appetite and decreasing energy expenditure. ${ }^{15,18}$ Leptin (LEP) is mainly secreted by adipocytes when the body has adiposity and/or the energy was replacement. Within the hypothalamus, LEP binds to orexigenic neurons and inhibits this pathway through AgRP/NPY production. Furthermore, LEP also binds to anorexigenic neurons and stimulates this pathway through the expression of proopiomelanocortin (POMC) and cocaine and amphetamine-related transcript (CART). Both proteins activate MC4R in the PVN, decreasing the appetite and increasing energy expenditure. ${ }^{6,18,19}$

In addition, other genes expressed in hypothalamic areas also appear to have a neuronal effect on energy balance and appetite, including brain-derived neurotrophic factor $(B D N F)$ and fat mass and obesity-associated (FTO) genes. ${ }^{7,13} B D N F$ has an important role in neuronal survival, maturation and differentiation during hypothalamic development, where it modulates energy metabolism. ${ }^{20-23}$ FTO encodes a demethylation enzyme that plays a central role in the regulation of food intake and energy expenditure in mice and humans. This is supported by studies showing that FTO variants have influence on satiety, food choices and energy intake. ${ }^{24-27}$ In rodent models, Fto overexpression in hypothalamus led to an increase of food consumption and body fat mass, while a reduced expression of Fto mRNA increased the energy expenditure and resulted in a lean phenotype. ${ }^{28,29}$

Individuals vary in their perceptions of hunger and satiety, and genetic variants associated with appetite regulation may predispose to obesity risk (Table 1). Consequently, it is important to understand these relations in order to design strategies for the prevention of obesity. Therefore, the aim of this study was to investigate whether polymorphisms belonging to genes expressed in the hypothalamic region could influence severe obesity susceptibility. Additionally, we also explored the role of these polymorphisms on obesity-related traits, blood pressure and biochemical parameters.

\section{Materials and methods Study population}

This case-control cross-sectional study enrolled men and women, aged 18 to 70 years from Rio de Janeiro, southeast of Brazil. A total of 527 participants were recruited between July 2012 and December 2017. The selection of this cohort was described previously. ${ }^{11}$ Briefly, inclusion criteria were participants with normal-weight (controls, 18.5 $\leq \mathrm{BMI}$ $\leq 24.9 \mathrm{~kg} / \mathrm{m}^{2}$ ) and obesity (cases, BMI $\geq 30 \mathrm{~kg} / \mathrm{m}^{2}$ ). ${ }^{30}$ The case group was recruited from a non-governmental organization, called Rescue Group to Self-Esteem and Citizenship of the Obese (in Portuguese, "Grupo de Resgate à Autoestima e Cidadania do Obeso"); and the control group was composed of volunteers from public hospitals in the same city. The exclusion criteria were pregnancy, lactation, and the use of medication to lose or gain weight directly. Pharmacological treatment for mental illness (depression and anxiety) and type 2 diabetes (T2D) was not an exclusion criterion for our study. Clinical and demographic information, anthropometric measurements, blood pressure and peripheral blood collection for biochemical and genetic analyses were obtained from all participants.

From the total of 527 subjects, a subsample was selected. Individuals with obesity with BMI lower than $35 \mathrm{~kg} / \mathrm{m}^{2}$ were excluded from the analyses $(n=31)$. Moreover, subjects who self-reported as Asian $(n=5)$ and indigenous $(n=1)$ were also excluded. Therefore, 490 participants were included in our 
Table I Candidate genes and genetic variants included in this study

\begin{tabular}{|c|c|c|c|c|c|c|}
\hline Gene & $\begin{array}{l}\text { Chromosome } \\
\text { location }\end{array}$ & Biological relevance & dbSNP\# & $\begin{array}{l}\text { SNP } \\
\text { location }\end{array}$ & MAF* & Previous studies \\
\hline $\begin{array}{l}\text { Agouti related } \\
\text { protein } \\
(A G R P)\end{array}$ & $16 q 22$ & $\begin{array}{l}\text { Endogenous antagonist of } \\
\text { melanocortin receptors } \\
\text { (MC4R and MC3R) that } \\
\text { regulates appetite and } \\
\text { energy expenditure. }\end{array}$ & rs5030980 & Exon 3 & 0.015 & $\begin{array}{l}\text { - Associated with BMI in } \\
\text { European Americans } \\
(n=1,982) \text { and body weight in } \\
\text { Quebec families ( } n=874))^{53,54} \\
\text { - No association with BMI in } \\
\text { Dutch adults ( } n=582 \text { ) and } \\
\text { Latvian population } \\
(n=789) . .^{2,57}\end{array}$ \\
\hline $\begin{array}{l}\text { Melanocortin } \\
4 \text { receptor } \\
(M C 4 R)\end{array}$ & $18 q 21.3 / 18 q 22$ & $\begin{array}{l}\text { Stimulation of MC4R } \\
\text { leads to a reduction in } \\
\text { energy intake and an } \\
\text { increased basal energy } \\
\text { expenditure. }\end{array}$ & rs 17782313 & $\begin{array}{l}\text { I88 kb } \\
\text { downstream } \\
\text { of } M C 4 R\end{array}$ & 0.240 & $\begin{array}{l}\text { - No association with biochem- } \\
\text { ical or anthropometric vari- } \\
\text { ables in individuals with } \\
\text { Northern Han Chinese ances- } \\
\text { try }(n=3,859){ }^{64} \\
\text { - No relation with anthropo- } \\
\text { metric and dietary para- } \\
\text { meters in a Brazilian childhood } \\
\text { cohort followed-up since birth } \\
\text { ( } n=745){ }^{14} \\
\text { - Associated with obesity sus- } \\
\text { ceptibility in a Japonese } \\
(n=I, I 29) \text {, Caucasian } \\
(n=I, 36 I) \text { and North Indians } \\
\text { cohorts }(n=696) .{ }^{35,59,65}\end{array}$ \\
\hline $\begin{array}{l}\text { Brain-derived } \\
\text { neurotrophic } \\
\text { factor (BDNF) }\end{array}$ & $|I| p \mid 3$ & $\begin{array}{l}\text { Protein involved in neu- } \\
\text { ronal survival, maturation } \\
\text { and differentiation during } \\
\text { central nervous system } \\
\text { development. }\end{array}$ & rs4074I34 & $\begin{array}{l}\text { 3 I kb of 3'- } \\
\text { flanking of } \\
\text { BDNF }\end{array}$ & 0.252 & $\begin{array}{l}\text { - Associated with BMI, WC, } \\
\text { fasting and postprandial glu- } \\
\text { cose, fasting serum insulin and } \\
\text { HOMA-IR in subjects with } \\
\text { Northern Han Chinese ances- } \\
\text { try }(n=3,859){ }^{64} \\
\text { - Linked to BMI and body } \\
\text { weight in large mixed cohort } \\
\text { ( } n=31,392){ }^{66} \\
\text { - Risk factor for obesity in } \\
\text { a Japanese cohort }(n=I, 129) .^{35}\end{array}$ \\
\hline $\begin{array}{l}\text { Ghrelin } \\
\text { (GHRL) }\end{array}$ & $3 p 26$ & $\begin{array}{l}\text { Orexigenic peptide that } \\
\text { modulates appetite, gas- } \\
\text { trointestinal motility, gas- } \\
\text { tric acid release and } \\
\text { pancreatic secretions. }\end{array}$ & 西 & Exon 4 & 0.083 & $\begin{array}{l}\text { - Carriers of the mutant allele }(T) \\
\text { showed a significant reduction } \\
\text { in BMI after } 52 \text { weeks of baria- } \\
\text { tric surgery }(n=100)^{67} \\
\text { - Positively associated with BMI } \\
\text { and obesity susceptibility in } \\
\text { a Japanese cohort }(n=5, I I 2) .^{10} \\
\text { - No association with obesity, } \\
\text { eating behavior and glucose } \\
\text { metabolisms in French families } \\
(n=2,334) . .^{5}\end{array}$ \\
\hline $\begin{array}{l}\text { Neuropeptide } \\
\text { Y (NPY) }\end{array}$ & $7 q 15.1$ & $\begin{array}{l}\text { This peptide regulates } \\
\text { energy homeostasis } \\
\text { thought binds to its } \\
\text { receptor on PVN. }\end{array}$ & rs535870237 & $\begin{array}{l}\text { I7-bp dele- } \\
\text { tion at } \\
\text { 5'UTR }\end{array}$ & 0.00039 & $\begin{array}{l}\text { - Observed in one Mexican } \\
\text { American family }(n=934) .{ }^{58}\end{array}$ \\
\hline
\end{tabular}

(Continued) 
Table I (Continued).

\begin{tabular}{|c|c|c|c|c|c|c|}
\hline Gene & $\begin{array}{l}\text { Chromosome } \\
\text { location }\end{array}$ & Biological relevance & dbSNP\# & $\begin{array}{l}\text { SNP } \\
\text { location }\end{array}$ & MAF* & Previous studies \\
\hline $\begin{array}{l}\text { Fat Mass } \\
\text { Obesity- } \\
\text { Associated } \\
\text { gene (FTO) }\end{array}$ & $16 q \mid 2.2$ & $\begin{array}{l}\text { Demethylation enzyme } \\
\text { involved in controlling of } \\
\text { energy homeostasis, } \\
\text { DNA methylation and } \\
\text { abiogenesis }\end{array}$ & rs9939609 & Intron I & 0.340 & $\begin{array}{l}\text { - No association with obesity } \\
\text { phenotype in Egyptian adoles- } \\
\text { cents and children; however, } \\
\text { the presence of the risk allele } \\
\text { was linked to higher LDL } \\
\text { cholesterol ( } n=200) .^{42} \\
\text { - Associated with morbid obe- } \\
\text { sity risk in the Brazilian adults } \\
(n=239) \text { and Mexican popula- } \\
\text { tion }(n=1,156){ }^{13,44} \\
\text { - Associated with satiety sensa- } \\
\text { tions }(n=70) \text {, food intake con- } \\
\text { trol }(n=97), \text { food choice } \\
(n=97) \text { and cardiorespiratory } \\
\text { fitness }(n=420){ }^{25,49,68}\end{array}$ \\
\hline
\end{tabular}

Abbreviations: BMI, Body mass index; dbSNP, Single nucleotide polymorphism database; HOMA-IR, Homeostatic model assessment - Insulin resistance; LDL, Low density lipoprotein; MAF, Minor allele frequency; MC3R, Melanocortin 3 receptor; PVN, Paraventricular nucleus; SNP, Single nucleotide polymorphism; UTR, Untranslated region; WC, Waist circumference.

analyses (controls, $\mathrm{n}=192$; cases, $\mathrm{n}=298$ ). This study was approved by the Ethics Committee of Oswaldo Cruz Foundation and was carried out according to the principles expressed in the Declaration of Helsinki (1964). All individuals accepted to participate and provided a written informed consent.

\section{Demographic variables}

Race/skin color was self-reported and categorized according to the criteria of the Demographic Census conducted by the Brazilian Institute of Geography and Statistics (white, brown, black, yellow [Asian] and indigenous). Marital status was stratified as single, married/cohabiting, separated/divorced and widower. Cigarette smoking status was classified as "never smoked" or "already smoked" (current smokers and exsmokers). Physical activity was classified as "yes", if the participants have been practicing activities during the last month, or "no". All information was self-reported and collected using standardized questionnaires by trained interviewers.

\section{Body composition and biochemical analyses}

All participants were examined following an overnight fast. Body weight, height, waist and hip circumferences were obtained for each participant. Waist circumference (WC) was measured at the midway between the iliac crest and the last costal arch. Hip circumference (HC) was measured around the greater trochanters. Further, BMI, inverted BMI, waist to weight ratio (WWR), waist to height ratio and waist to hip ratio (WHR) were calculated in order to estimate the pattern of fat distribution. BMI was calculated as weight (kilograms) divided by the square of height (meters). Body adiposity index (BAI) estimates the percentage of total fat and was calculated by the formula: hip circumference/(height $\left.{ }^{1.5}\right)-18 .{ }^{31}$ Blood pressure was recorded in the sitting position using a wrist blood pressure monitor. Hypertension was diagnosed by blood pressure equal or higher than $140 \times 90 \mathrm{~mm} \mathrm{Hg}$, or use of antihypertensive drug therapy. ${ }^{32}$

Blood samples were collected in order to measure fasting plasma glucose, total cholesterol (TC), highdensity lipoprotein cholesterol (HDL-c) and triglyceride (TG) using the oxidase-peroxidase method (BioSystems). Low-density lipoprotein cholesterol (LDL-c) was calculated by the Friedewald formula (LDL-c $=$ TC - HDLc - TG/5). Additionally, C-reactive protein (CRP) was measured by the latex agglutination method and glycated hemoglobin was evaluated using turbidimetric inhibition immunoassay (TINIA). Individuals using medication for these biochemical parameters or blood pressure had their values excluded from the statistical analyses.

\section{Genotyping}

Genomic DNA was isolated from peripheral blood leukocytes using the QIAamp Blood Kit (Qiagen, Valencia, CA, USA) according to the manufacturer's protocol. Genotypes for $A G R P$ (rs5030980; C>T), BDNF (rs4074134; C > T), FTO 
(rs9939609; T>A), GHRL (rs696217; G>T) and $M C 4 R$ (rs17782313; T $>$ C) polymorphisms were obtained by realtime PCR allelic discrimination using TaqMan ${ }^{\circledR}$ assays (ThermoFisher, Foster City, CA, USA). Amplification was carried out in a StepOne ${ }^{\circledR}$ Plus Real Time PCR System and data analyses were done using StepOne software v2.3.

For the NPY gene, a 17 bp deletion (rs535870237) was analyzed by conventional PCR (Supplementary material 1).

\section{Statistical analysis}

Normality of continuous variables was analyzed using Kolmogorov-Smirnov and Shapiro-Wilk tests. Continuous parameters were presented as median and interquartile, since they were shown as non-normally distributed data. Categorical variables were presented as number and percentages. Differences between the case and control groups were evaluated using Mann-Whitney (quantitative parameters) or Chi-square tests (qualitative parameters). The effect of potential variables (age, gender, race/skin, marital status, smoking status and physical activity practice) was investigated for severe obesity and was incorporated as covariate in the model when $P \leq 0.05$.

Genotype and allele frequencies were estimated by gene counting. Hardy-Weinberg Equilibrium (HWE) was checked for all polymorphisms using Chi-square test. Association of each polymorphism with obesity status was performed by logistic regression analysis in additive, dominant and recessive models. Odds ratio (OR) and 95\% confidence intervals (CI) were also calculated. The same analyses were also performed using allele frequencies. All analyses were adjusted for age and gender (model 1) and further adjusted for age, gender, race/skin color, marital status and exercises habits (model 2). Additionally, genotype score counting was used to calculate the number of risk alleles for each participant as earlier described by Shabana and coworkers. ${ }^{33}$ The influence of the combined risk alleles on severe obesity susceptibility was tested by logistic regression and adjusted for the covariates (model 2). The number of risk alleles per group was shown as mean (standard deviation) and the comparison between the groups was carried out by independent sample $t$-tests.

The influence of each polymorphism on the quantitative variables related to obesity was tested using linear regression analysis after a logarithmic transformation of these parameters. Gender, age, race/skin color, marital status and exercises habits were used as possible confounding variables for body weight, BMI, inverted BMI and WWR. Those parameters and BMI were used as covariates for all other biochemical, blood pressure and anthropometric parameters.

All statistic tests were performed using SPSS software version for Windows (SPSS, Chicago, IL, USA). Since different polymorphisms were studied, a Bonferroni's correction for multiple comparisons was used and a corrected $P$-value of 0.01 was applied as a significance cutoff.

\section{Results}

The characteristics of study population are shown in Table S1. The cohort comprised 490 participants, 192 normal-weights (median of BMI $=22.8[21.1 ; 23.9] \mathrm{kg} / \mathrm{m}^{2}$ ) and 298 severely obese (median of BMI $=46.8[41.8 ; 52.8] \mathrm{kg} / \mathrm{m}^{2}$ ). In terms of clinical and demographic characteristics, a reduced prevalence of cases with white skin and singles were observed, whereas controls were significantly younger and practiced more physical activities. All those variables were included as covariates in the case-control association analyses in order to remove bias from confounding factors. As expected, participants with severe obesity had higher anthropometric, blood pressure and biochemical levels when compared to the normal-weight subjects. The exceptions were in height, inverted BMI, waist to height ratio and HDL-cholesterol, in which the control group had higher values. In addition, the proportion of subjects with hypertension and T2D was $69.8 \%$ and $20.2 \%$ among severely obese patients, respectively, whereas the values for the controls were $4.7 \%$ and $0 \%$, respectively.

\section{Association of the studied polymorphisms with severe obesity}

Allele and genotype frequencies were obtained for all polymorphisms (Table 2). AGRP rs5030980 polymorphism showed a low frequency in our sample, and we did not find any homozygous for the risk allele (TT). Genetic analyses of $A G R P$ rs5030980 were performed using only wild-type and heterozygous genotypes. Regarding GHRL rs696217 polymorphism, we identified only one homozygous subject for the risk allele (T) and our analyses were carried out in the dominant model (GG vs GT+TT). Furthermore, no 17-bp deletion (rs535870237) was identified in the NPY gene. Therefore, only five polymorphisms were included in our analyses (rs5030980, rs4074134, rs9939609, rs696217 and rs17782313). None of them deviated from HWE for both case and control groups $(P>0.05$; data not shown).

Results of our case-control analyses are also presented in Table 2. The comparison between genotype frequencies showed that FTO rs9939609 AA genotype was associated with severe 
Table 2 Association of AGRP, BDNF, FTO, GHRL and MC4R polymorphisms with obesity susceptibility

\begin{tabular}{|c|c|c|c|c|c|c|}
\hline \multirow[t]{2}{*}{ Gene (polymorphism) } & \multirow{2}{*}{$\begin{array}{l}\text { Control } \\
n=\mid 92(\%)\end{array}$} & \multirow{2}{*}{$\begin{array}{l}\text { Case } \\
\mathrm{n}=298(\%)\end{array}$} & \multicolumn{2}{|l|}{ Model I } & \multicolumn{2}{|l|}{ Model 2} \\
\hline & & & OR $(95 \% \mathrm{CI})$ & $P$ & OR $(95 \% \mathrm{CI})$ & $P$ \\
\hline $\begin{array}{l}\text { AGRP }(\mathbf{r s 5 0 3 0 9 8 0})^{\mathbf{a}} \\
\text { Genotype } \\
\text { CC } \\
\text { CT } \\
\text { Allele } \\
\text { C } \\
\text { T }\end{array}$ & $\begin{array}{l}179(93.2) \\
13(6.8) \\
371(96.6) \\
13(3.4)\end{array}$ & $\begin{array}{l}278(93.3) \\
20(6.7) \\
576(96.6) \\
20(3.4)\end{array}$ & $\begin{array}{l}1.00 \text { (Ref.) } \\
1.08(0.50-2.33) \\
1.00 \text { (Ref.) } \\
1.08(0.50-2.33)\end{array}$ & $\begin{array}{l}- \\
0.841 \\
- \\
0.841\end{array}$ & $\begin{array}{l}\text { I.00 (Ref.) } \\
\text { I.II (0.47-2.59) } \\
\text { I.00 (Ref.) } \\
\text { I.II (0.47-2.59) }\end{array}$ & $\begin{array}{l}- \\
0.811 \\
- \\
0.811\end{array}$ \\
\hline $\begin{array}{l}\text { BDNF (rs4074l34) } \\
\text { Genotype } \\
\text { CC } \\
\text { CT } \\
\text { TT } \\
\text { Dominant Model } \\
\text { CC } \\
\text { CT+TT } \\
\text { Recessive Model } \\
\text { CC+CT } \\
\text { TT } \\
\text { Allele } \\
\text { C } \\
\text { T }\end{array}$ & $\begin{array}{l}122(63.6) \\
64(33.3) \\
6(3.1) \\
122(63.5) \\
70(36.5) \\
186(96.9) \\
6(3.1) \\
308(80.2) \\
76(19.8)\end{array}$ & $\begin{array}{l}204(68.5) \\
82(27.5) \\
12(4.0) \\
204(68.5) \\
94(31.5) \\
286(96.0) \\
12(4.0) \\
490(82.2) \\
106(17.8)\end{array}$ & $\begin{array}{l}\text { I.00 (Ref.) } \\
0.79 \text { (0.5I-I.22) } \\
\text { I. } .42 \text { (0.47-4.23) } \\
1.00 \text { (Ref.) } \\
0.84 \text { (0.55-I.28) } \\
1.00 \text { (Ref.) } \\
1.53 \text { (0.5I-4.58) } \\
1.00 \text { (Ref.) } \\
0.92 \text { (0.65-I.32) }\end{array}$ & $\begin{array}{l}- \\
0.293 \\
0.536 \\
- \\
0.419 \\
- \\
0.451 \\
- \\
0.663\end{array}$ & $\begin{array}{l}1.00 \text { (Ref.) } \\
0.87 \text { (0.54-I.40) } \\
2.12 \text { (0.60-7.50) } \\
1.00 \text { (Ref.) } \\
0.95 \text { (0.60-I.50) } \\
1.00 \text { (Ref.) } \\
2.22 \text { (0.63-7.77) } \\
1.00 \text { (Ref.) } \\
0.92 \text { (0.63-I.34) }\end{array}$ & $\begin{array}{l}- \\
0.571 \\
0.242 \\
- \\
0.819 \\
- \\
0.212 \\
- \\
0.667\end{array}$ \\
\hline $\begin{array}{l}\text { FTO (rs9939609) } \\
\text { Genotype } \\
\text { TT } \\
\text { TA } \\
\text { AA } \\
\text { Dominant Model } \\
\text { TT } \\
\text { TA+AA } \\
\text { Recessive Model } \\
\text { TT+TA } \\
\text { AA } \\
\text { Allele } \\
\text { T } \\
\text { A }\end{array}$ & $\begin{array}{l}71(37.0) \\
85(44.3) \\
36(18.7) \\
71(37.0) \\
121(63.0)\end{array}$ & $\begin{array}{l}73(24.5) \\
146(49.0) \\
79(26.5) \\
73(24.5) \\
225(75.5) \\
219(73.5) \\
79(26.5) \\
292(49.0) \\
304(51.0)\end{array}$ & $\begin{array}{l}\text { I.00 (Ref.) } \\
\text { I.66 (I.05-2.63) } \\
2.24 \text { (I.28-3.92) } \\
\text { I.00 (Ref.) } \\
\text { I.82 (I.I9-2.80) } \\
\text { I.00 (Ref.) } \\
\text { I.65 (I.0I-2.69) } \\
\text { I.00 (Ref.) } \\
\text { I.53 (I.I4-2.00) }\end{array}$ & $\begin{array}{l}- \\
0.031 \\
\mathbf{0 . 0 0 5} \\
- \\
\mathbf{0 . 0 0 6} \\
- \\
0.044\end{array}$ & $\begin{array}{l}1.00 \text { (Ref.) } \\
1.80 \text { (I.09-2.98) } \\
2.24 \text { (I.22-4.I2) } \\
1.00 \text { (Ref.) } \\
1.94 \text { (I.2I-3.09) } \\
1.00 \text { (Ref.) } \\
1.58 \text { (0.93-2.70) } \\
1.00 \text { (Ref.) } \\
1.53 \text { (I.13-2.07) }\end{array}$ & $\begin{array}{l}- \\
0.021 \\
0.010 \\
- \\
0.006 \\
- \\
0.092 \\
- \\
0.006\end{array}$ \\
\hline $\begin{array}{l}\text { GHRL (rs696217) } \\
\text { Genotype } \\
\text { GG } \\
\text { GT+TT } \\
\text { Allele } \\
\text { G } \\
\text { T }\end{array}$ & $\begin{array}{l}177(92.2) \\
15(7.8) \\
369(96.1) \\
15(3.9)\end{array}$ & $\begin{array}{l}277(93.0) \\
21(7.0) \\
575(96.5) \\
21(3.5)\end{array}$ & $\begin{array}{l}\text { I.00 (Ref.) } \\
0.76(0.35-1.63) \\
1.00 \text { (Ref.) } \\
0.76(0.35-1.63)\end{array}$ & $\begin{array}{l}- \\
- \\
0.475\end{array}$ & $\begin{array}{l}\text { I.00 (Ref.) } \\
0.91 \text { (0.38-2.18) } \\
1.00 \text { (Ref.) } \\
0.91 \text { (0.38-2.I8) }\end{array}$ & $\begin{array}{l}- \\
0.838 \\
- \\
0.838\end{array}$ \\
\hline $\begin{array}{l}\text { MC4R (rs I 77823 I } 3) \\
\text { Genotype } \\
\text { TT } \\
\text { TC } \\
\text { CC }\end{array}$ & $\begin{array}{l}126(65.6) \\
58(30.2) \\
8(4.1)\end{array}$ & $\begin{array}{l}172(57.7) \\
113(37.9) \\
13(4.4)\end{array}$ & $\begin{array}{l}\text { I.00 (Ref.) } \\
1.28(0.84-1.96) \\
1.20(0.46-3.16)\end{array}$ & $\begin{array}{l}- \\
0.254 \\
0.706\end{array}$ & $\begin{array}{l}\text { I.00 (Ref.) } \\
\text { I.39 (0.87-2.23) } \\
\text { I.09(0.38-3.10) }\end{array}$ & $\begin{array}{l}- \\
0.170 \\
0.872\end{array}$ \\
\hline
\end{tabular}

(Continued) 
Table 2 (Continued).

\begin{tabular}{|c|c|c|c|c|c|c|}
\hline \multirow[t]{2}{*}{ Gene (polymorphism) } & \multirow{2}{*}{$\begin{array}{l}\text { Control } \\
n=192(\%)\end{array}$} & \multirow{2}{*}{$\begin{array}{l}\text { Case } \\
n=298(\%)\end{array}$} & \multicolumn{2}{|l|}{ Model I } & \multicolumn{2}{|l|}{ Model 2} \\
\hline & & & OR (95\% Cl) & $P$ & OR $(95 \% \mathrm{CI})$ & $P$ \\
\hline \multicolumn{7}{|l|}{ Dominant Model } \\
\hline TT & $126(65.6)$ & 172 (57.7) & I.00 (Ref.) & - & I.00 (Ref.) & - \\
\hline $\mathrm{TC}+\mathrm{CC}$ & $66(34.4)$ & $126(42.3)$ & $1.27(0.84-1.19)$ & 0.249 & $1.35(0.96-2.11)$ & 0.193 \\
\hline \multicolumn{7}{|l|}{ Recessive Model } \\
\hline $\mathrm{TT}+\mathrm{TC}$ & $184(95.8)$ & $285(95.6)$ & I.00 (Ref.) & - & I.00 (Ref.) & - \\
\hline CC & $8(4.2)$ & $13(4.4)$ & I.IO (0.42-2.87) & $0.84 I$ & $0.97(0.35-2.74)$ & 0.962 \\
\hline \multicolumn{7}{|l|}{ Allele } \\
\hline $\mathrm{T}$ & $310(80.7)$ & 457 (76.7) & I.00 (Ref.) & - & I.00 (Ref.) & - \\
\hline C & $74(19.3)$ & $139(23.3)$ & $1.20(0.85-1.69)$ & 0.299 & $1.23(0.84-1.80)$ & 0.284 \\
\hline
\end{tabular}

Notes: $P$-value and OR were calculated using logistic regression and adjusted for gender and age (Model I). P¥-value and OR were calculated using logistic regression and adjusted for age, gender, race/skin color, marital status and exercises habits (Model 2). ${ }^{2}$ No homozygous mutant was identified.

Abbreviations: AGRP, protein related to aguti; BDNF, brain-derived neurotrophic factor; Cl, confidence interval; FTO, fat mass and obesity-associated gene; GHRL, ghrelin; MC4R, melanocortin 4 receptor; OR, Odds ratio; Ref, Reference.

obesity. However, this relation did not remain after adjusting for covariates (model 2) and correcting for multiple testing. This polymorphism was also associated with the dominant model $(\mathrm{OR}=1.94$ [1.21-3.09]; $P=0.006)$. Allelic tests showed that individuals carrying the mutant allele (A) were 1.5 times more likely to develop this phenotype when compared to the control group $(\mathrm{OR}=1.53$ [1.13-2.07]; $P=0.006)$. Carriers of at least one mutated allele (A) had a 53\% higher risk of becoming severely obese. No association of $A G R P$ rs5030980, BDNF rs4074134, GHRL rs696217 and MC4R rs17782313 polymorphisms with obesity was observed in our study.

\section{Effect of combined risk alleles on obesity susceptibility}

We investigated the influence of the gene score on obesity status. The results showed that $10.1 \%$ of severely obese had more than four risk alleles, whereas in normal-weight group only $5.7 \%$ of individuals had these number of risk alleles. The average number of risk alleles was higher in cases $(1.98 \pm 1.13)$ than controls $(1.74 \pm 1.10)$; however, this difference was not statistically significant $(P=0.463)$. The risk of becoming obese increase 1.2 times for each risk allele added $(\mathrm{OR}=1.27$ [1.04-1.55]; $P=0.016$ ) after adjusting for covariates. This association did not remain after correcting for multiple tests.

\section{Association of polymorphisms with metabolic parameters}

We also evaluated the potential influence of the studied polymorphisms on anthropometric, blood pressure and biochemical parameters (Table S2). Our results showed that FTO rs9939609 was associated with body weight, BMI, WWR and inverted BMI. Individuals with FTO rs9939609 AA genotype exhibited higher values of body weight $(\beta=0.030 \pm 0.010 ; P=0.002)$ and BMI $(\beta=0.032 \pm 0.009 ; P=0.001)$ when compared to TA and TT genotypes. These individuals also had lower levels of WWR $(\beta=$ $-0.012 \pm 0.004 ; P=0.003)$ and inverted BMI $(\beta=-0.029 \pm 0.010$; $P=0.003)$. MC4R rs17782313 was negatively associated with CRP $(\beta=-0.098 \pm 0.043 ; P=0.025$ ); however, this relation did not remain after correcting for multiple testing. None of the other polymorphisms was seen linked to the metabolic parameters.

\section{Discussion}

In the present study, we evaluated the contribution of variants in six genes (AGRP, BDNF, FTO, GHRL, MC4R and NPY) in the development of severe obesity in a Brazilian cohort. The products of these genes are expressed or act in the hypothalamic region, and they have been directly or indirectly associated with food intake and basal energy expenditure. ${ }^{6,34}$ Several polymorphisms were identified in these genes; however, their association with obesity varies with the ethnicity of the population. $^{12,14,33-35}$

Interestingly, FTO was locus that presented the most significant association with severe obesity in our cohort. Previous GWA studies have reported that polymorphisms in intron 1 of this gene are associated with obesity susceptibility. ${ }^{36-38}$ Furthermore, the relationship between FTO rs9939609 and obesity has been reported in Brazilian and in other populations. ${ }^{34,39-41}$ However, FTO rs9939609 does not appear to influence obesity susceptibility in Egyptian and six Oceanic populations. ${ }^{42,43}$ 
León-Mimila et al ${ }^{13}$ reported that FTO rs9939609 was associated with obesity in a Mexican adult population. Interestingly, the strongest and most significant relation was observed in individuals with morbid obesity (BMI $\geq$ $40 \mathrm{~kg} / \mathrm{m}^{2}$ ). This positive association was also observed in a Brazilian and an Italian cohort. ${ }^{44,45}$ García-Solís reported a similar significant association between FTO rs9939609 and obesity in Mexican children. ${ }^{34}$ However, this finding was not replicated in a different children group from the same population or in an Egyptian cohort. ${ }^{13,42}$

Regarding the influence of polymorphisms on phenotype variables, we observed an association of FTO rs9939609 with several anthropometric parameters (body weight, BMI, WWR and inverted BMI), after excluding possible confounders. However, this polymorphism was not associated with the biochemical parameters or blood pressure. Similarly, Marcadenti et $\mathrm{al}^{46}$ reported that this polymorphism has a positive association with BMI and neck circumference in patients with hypertension from the south of Brazil. They did not observe an effect of FTO rs9939609 also on blood pressure and other anthropometric variables in their overall population. León-Mimila et $\mathrm{al}^{13}$ observed that the Mexican Indigenous adults carrying one risk alleles had an increase of $1.22 \mathrm{~kg} / \mathrm{m}^{2}$ in BMI. They also reported that this polymorphism was marginally associated with lower triglyceride levels in MexicanMestizo adults, but no association was found with BMI, WC, HC, glucose, TC or HDL-c. Sentinelli et $\mathrm{al}^{45}$ observed that rs9939609 was associated with BMI and WC. However, no association was found between this polymorphism and biochemical parameters, similar to our results. In Egyptian children and adolescents, FTO rs9939609 was only correlated with LDL-cholesterol. ${ }^{42}$ Reasons for the discrepancies might be explained by differences in the genetic background as well as the sample criteria, since we have selected only patients with severe obesity and adults.

FTO is mainly expressed in the hypothalamus and encodes a nucleic acid demethylase which cleaves the methyl groups from nucleotides in the DNA and in the RNA. This nucleic acid demethylation activity may suggest that FTO influences the development of obesity at the epigenetic level. ${ }^{47}$ Despite the fact that the function of FTO is not totally understood, it is suggested that it may have an important role on satiety, food consumption and energy expenditure. ${ }^{25-27}$ This is supported by studies with murine models that lack FTO function and/or Fto expression. These mice presented an increase in energy expenditure and a lean phenotype. ${ }^{28,48}$ In addition, the overexpression of Fto resulted in increased food intake, body weight and fat mass. ${ }^{29}$

Magno et $\mathrm{al}^{25}$ reported that FTO rs9939609 may have an important role in the hunger and satiety sensations in a cohort of morbidly obese females from Brazil. Cecil et al ${ }^{49}$ also demonstrated that this polymorphism influenced appetite and food choice. FTO rs9939609 polymorphism is located in intron 1 and it seems to exert functional effects on FTO by modulation its expression or it is in linkage disequilibrium with another causative genetic variant. ${ }^{47,50}$ More functional studies are required to elucidate the role of FTO rs99309609 in the development of obesity.

Furthermore, we have studied different genetic variants in the leptin-melanocortin pathway, but they were not associated with severe obesity susceptibility as well as obesity-related traits in our cohort. As shown in Table 1, the association between these polymorphisms and obesity is controversial in the literature. GHRL rs696217 was previously related to adiposity in the Japanese population, in which carriers of one risk allele had an increase of $0.18 \mathrm{~kg} / \mathrm{m}^{2}$ of BMI. ${ }^{10}$ However, this positive association was not observed in a cohort of Italians and French families, similar to our results. ${ }^{51,52}$ The discrepancies may be explained by the different genetic backgrounds between the populations, since the frequency of the risk allele is $20 \%$ in Japanese individuals and only $8 \%$ in Caucasians. $^{10,52}$

$A G R P$ rs5030980 polymorphism was associated with anorexia nervosa and also a reduction in BMI, body weight and body fat. ${ }^{53-55}$ In addition, carriers of wild-type genotype were related to total and abdominal adiposity in individuals with late-onset obesity. ${ }^{56}$ Controversially, this polymorphism was not associated with BMI in cohorts from Latvia and the Netherlands. ${ }^{12,57}$ Regarding NPY gene, a 17-bp deletion in the 5'UTR was analyzed in our study. We did not find individuals carrying this deletion, suggesting that this genetic variant is rare in our population. Bray et al. ${ }^{58}$ identified this deletion in only one family with morbid obesity. Additionally, the 1000 genomes project also observed a low frequency of this variant in the general population $(0.04 \%)$.

MC4R rs 17782313 polymorphism is located near the gene and was previously associated with obesity and anthropometric variables in Asian and European populations. ${ }^{59-61}$ However, such results were not found in a cohort of Africans and East Asians. ${ }^{35,62}$ In this present study, we observed that the genotype and allele 
frequencies were similar between case and control groups. Grant et al. ${ }^{63}$ found a similar result, in which no association was observed between $M C 4 R$ rs 17782313 and obesity in Afro-American individuals. Thus, all these findings suggest that the influence of $M C 4 R$ rs17782313 on the risk for obesity is dependent on the ethnic group.

Finally, few studies have analyzed BDNF rs4074134 variation and most of them were in Asian populations. ${ }^{35,64}$ Han et $\mathrm{al}^{64}$ found that this polymorphism was associated with the reduction of BMI, WC, glucose, insulin and the risk for $\mathrm{T} 2 \mathrm{D}$ in the Chinese population. However, this genetic variation was positively associated with obesity susceptibility in a sample of Japanese subjects. The discrepancy of these results, and ours, could be explained by differences in the genetic background between the populations and the selection criteria of the samples.

Several limitations should be taken into account before interpreting the results. Despite including race/ skin color as covariates, we did not genotype ancestry markers to control for population substructures. We were unable to consider the fluctuation over time of anthropometric, biochemical and blood pressure parameters, since we performed a cross-sectional study. We were not able to exclude patients treated for mental illness and T2D, which may impact the parameters measured. In addition, we do not have information about energy intake, appetite or satiety. Finally, we cannot completely exclude the role of environmental variables, which could impact on the development of severe obesity.

\section{Conclusion}

Obesity is caused by the interaction between the individual genetic background and environmental factors, especially due to increased food intake and reduced energy expenditure. It is known that there is a specific circuit in the hypothalamus which can control energy balance. Genetic variants in the genes that act on this system may have an important role in obesity susceptibility. In our study, a significant association between severe obesity and FTO rs9939609 was found in our sample. Additionally, the presence of FTO risk allele was associated with higher body weight and BMI, and lower inverted BMI and WWR. No association was observed in the other studied polymorphisms. These finds suggest that FTO has an important role in severe obesity risk in a Brazilian population.

\section{Acknowledgments}

The author would like to thank the participants who kindly agreed to join in this study. We are grateful to Nereida Proença da Fonseca for her great technical assistance and Rosimere Lima for her excellent work with patients in GRACO. This work was supported by Oswaldo Cruz Foundation (FIOCRUZ, Rio de Janeiro - Brazil), National Council for Scientific and Technological Development $(\mathrm{CNPq})$ and Coordination for the Improvement of Higher Education Personnel (CAPES).

\section{Disclosure}

The authors report no conflicts of interest in this work.

\section{References}

1. World Health Organization [Internet]. Obesity and overweight; 2018 [cited August 22, 2018]. Available from: http://www.who.int/media centre/factsheets/fs311/en/. Accessed August 22, 2018.

2. Di Cesare M, Bentham J, Stevens GA, et al. Trends in adult body-mass index in 200 countries from 1975 to 2014: A pooled analysis of 1698 population-based measurement studies with 19.2 million participants. Lancet. 2016;387(10026):1377-1396. doi:10.1016/S0140-6736(16)30054-X

3. Ng M, Fleming T, Robinson M, et al. Global, regional, and national prevalence of overweight and obesity in children and adults during 1980-2013: a systematic analysis for the global burden of disease study 2013. Lancet. 2014;384(9945):766-781. doi:10.1016/S01406736(14)60460-8

4. Kitahara CM, Flint AJ, de Gonzalez AB, et al. Association between class III obesity (BMI of $40-59 \mathrm{~kg} / \mathrm{m} 2$ ) and mortality: a pooled analysis of 20 prospective studies. PLoS Med. 2014;11(7): e1001673. doi:10.1371/journal.pmed.1001673

5. Velázquez-Fernández D, Mercado-Celis G, Flores-Morales J, et al Analysis of gene candidate SNP and ancestral origin associated to obesity and postoperative weight loss in a cohort of obese patients undergoing RYGB. Obes Surg. 2017;27(6):1481-1492. doi:10.1007/ s11695-016-2501-9

6. Da Fonseca ACP, Mastronardi C, Johar A, Arcos-Burgos M, PazFilho G. Genetics of non-syndromic childhood obesity and the use of high-throughput DNA sequencing technologies. $J$ Diabetes Complications. 2017;31(10):1549-1561. doi:10.1016/j.jdiacomp. 2017.04.026

7. Willer CJ, Speliotes EK, Loos RJF, et al. Six new loci associated with body mass index highlight a neuronal influence on body weight regulation. Nat Genet. 2009;41(1):25-34. doi:10.1038/Ng.287

8. Speliotes EK, Willer CJ, Berndt SI, et al. Association analyses of 249,796 individuals reveal 18 new loci associated with body mass index. Nat Genet. 2010;42(11):937-948. doi:10.1038/ng.686

9. Paz-Filho G, Mastronardi CA, Licinio J. Leptin treatment: facts and expectations. Metabolism. 2015;64(1):146-156. doi:10.1016/j. metabol.2014.07.014

10. Imaizumi T, Ando M, Nakatochi M, et al. Effect of dietary energy and polymorphisms in BRAP and GHRL on obesity and metabolic traits. Obes Res Clin Pract. 2016. 12:39-48.

11. Fonseca ACP, Ochioni AC, Martins RDS, et al. Adiponectin, retinoic acid receptor responder 2 , and peroxisome proliferator-activated receptor- $\gamma$ coativator- 1 genes and the risk for obesity. Dis Markers. 2017;2017. doi: $10.1155 / 2017 / 5289120$ 
12. Kalnina I, Kapa I, Pirags V, Ignatovica V, Schiöth HB, Klovins J. Association between a rare SNP in the second intron of human Agouti related protein gene and increased BMI. BMC Med Genet. 2009;10(1):63. doi:10.1186/1471-2350-10-63

13. León-Mimila P, Villamil-Ramírez H, Villalobos-Comparán M, et al. Contribution of common genetic variants to obesity and obesity-related traits in mexican children and adults. PLoS One. 2013;8(8):e70640. doi:10.1371/journal.pone.0070640

14. Zandona MR, Sangalli CN, Campagnolo PDB, Vitolo MR, Almeida S, Mattevi VS. Validation of obesity susceptibility loci identified by genome-wide association studies in early childhood in South Brazilian children. Pediatr Obes. 2017;12(1):85-92. doi:10.1111/ijpo.12113

15. Cone RD. Anatomy and regulation of the central melanocortin system. Nat Neurosci. 2005;8(5):571-578. doi:10.1038/nn1455

16. Larder R, Lim CT, Coll AP. Genetic aspects of human obesity. Handb Clin Neurol. 2014;124:93-106.

17. Sutton AK, Myers MG, Olson DP. the role of PVH circuits in leptin action and energy balance. Annu Rev Physiol. 2016;78(1):207-221. doi:10.1146/annurev-physiol-021115-105347

18. Vetter ML, Faulconbridge LF, Webb VL, Wadden TA. Behavioral and pharmacologic therapies for obesity. Nat Rev Endocrinol. 2010;6 (10):578-588. doi:10.1038/nrendo.2010.121

19. Albuquerque D, Stice E, Rodríguez-López R, Manco L, Nóbrega C. Current review of genetics of human obesity: from molecular mechanisms to an evolutionary perspective. Mol Genet Genomics. 2015;290:1991. doi:10.1007/s00438-015-1015-9

20. Thoenen H. Neurotrophins and neuronal plasticity. Science. 1995;270 (5236):593-598

21. Ranadive SA, Vaisse C. Lessons from extreme human obesity: monogenic disorders. Endocrinol Metab Clin North Am. 2008;37 (3):733-751. doi:10.1016/j.ecl.2008.07.003

22. Yilmaz Z, Kaplan AS, Tiwari AK, et al. The role of leptin, melanocortin, and neurotrophin system genes on body weight in anorexia nervosa and bulimia nervosa. $J$ Psychiatr Res. 2014;55:77-86. doi:10.1016/j.jpsychires.2014.04.005

23. De Luis DA, Izaola O, Primo D, Pacheco D. Effect of the rs 10767664 variant of the brain-derived neurotrophic factor gene on weight change and cardiovascular risk factors in morbidly obese patients after biliopancreatic diversion surgery. Lifestyle Genom. 2016;9(2-4):116-122.

24. McCaffery JM, Papandonatos GD, Peter I, et al. Obesity susceptibility loci and dietary intake in the look AHEAD trial. Am J Clin Nutr. 2012;95(6):1477-1486. doi:10.3945/ajen.111.026955

25. Magno FCCM, Guaraná HC, Fonseca ACP, et al. Influence of FTO rs9939609 polymorphism on appetite, ghrelin, leptin, IL6, TNF $\alpha$ levels, and food intake of women with morbid obesity. Diabetes Metab Syndr Obes. 2018;11:199-207. doi:10.2147/DMSO.S154978

26. Rivas AMO, Santos JL, Valladares MA, Cameron J, Goldfield G. Association of the FTO fat mass and obesity-associated gene rs9939609 polymorphism with rewarding value of food and eating behavior in Chilean children. Nutrition. 2018;54:105-110. doi:10.1016/j.nut.2018.03.001

27. Qi Q, Kilpeläinen TO, Downer MK, et al. FTO genetic variants, dietary intake and body mass index: insights from 177330 individuals. Hum Mol Genet. 2014;23(25):6961-6972. doi:10.1093/hmg/ddu411

28. Church C, Lee S, Bagg EAL, et al. A mouse model for the metabolic effects of the human fat mass and obesity associated FTO gene. PLoS Genet. 2009;5(8):e1000599. doi:10.1371/journal.pgen.1000599

29. Church C, Moir L, McMurray F, et al. Overexpression of Fto leads to increased food intake and results in obesity. Nat Genet. 2010;42 (12):1086-1092. doi:10.1038/ng.713

30. World Health Organization. Obesity: preventing and managing the global epidemic. n. 894. World Health Organization, 2000.

31. Bergman RN, Stefanovski D, Buchanan TA, et al. A better index of body adiposity. Obesity. 2011;19(5):1083-1089. doi:10.1038/oby.2011.38
32. Chobanian AV. National heart, lung, and blood institute; national high blood pressure education program coordinating committee. seventh report of the joint national committee on prevention, detection, evaluation, and treatment of high blood pressure. Hypertension. 2003;42:1206-1252. doi:10.1161/01.HYP.0000107 251.49515.c2

33. Shabana HS. Effect of the common fat mass and obesity associated gene variants on obesity in Pakistani population: a case-control study. Biomed Res Int. 2015;2015:1-8. doi:10.1155/2015/852920

34. García-Solís P, Reyes-Bastidas M, Flores K, et al. Fat mass obesity-associated (FTO)(rs9939609) and melanocortin 4 receptor (MC4R)(rs17782313) SNP are positively associated with obesity and blood pressure in Mexican school-aged children. Br J Nutr. 2016;116(10):1834-1840. doi:10.1017/S0007114516003779

35. Hotta K, Nakamura M, Nakamura T, et al. Association between obesity and polymorphisms in SEC16B, TMEM18, GNPDA2, BDNF, FAIM2 and MC4R in a Japanese population. J Hum Genet. 2009;54(12):727-731. doi:10.1038/jhg.2009.106

36. Dina C, Meyre D, Gallina S, et al. Variation in FTO contributes to childhood obesity and severe adult obesity. Nat Genet. 2007;39 (6):724-726. doi:10.1038/ng2048

37. Frayling TM, Timpson NJ, Weedon MN, et al. A common variant in the FTO gene is associated with body mass index and predisposes to childhood and adult obesity. Science. 2007;316(5826):889-894. doi:10.1126/science. 1141634

38. Scuteri A, Sanna S, Chen W-M, et al. Genome-wide association scan shows genetic variants in the FTO gene are associated with obesity-related traits. PLoS Genet. 2007;3(7):e115. doi:10.1371/journal.pgen.0030115

39. Ramos RB, Casanova GK, Maturana MA, Spritzer PM. Variations in the fat mass and obesity-associated (FTO) gene are related to glucose levels and higher lipid accumulation product in postmenopausal women from southern Brazil. Fertil Steril. 2011;96(4):974-979. doi:10.1016/j.fertnstert.2011.07.1148

40. Albuquerque D, Nóbrega C, Manco L. Association of FTO polymorphisms with obesity and obesity-related outcomes in Portuguese children. PLoS One. 2013;8(1):e54370. doi:10.1371/journal.pone.0054370

41. Guclu-Geyik F, Onat A, Yuzbasiogulları AB, et al. Risk of obesity and metabolic syndrome associated with FTO gene variants discloses clinically relevant gender difference among Turks. Mol Biol Rep. 2016;43(6):485-494. doi:10.1007/s11033-016-3992-0

42. Abdelmajed SS, Youssef M, Zaki ME, Hassan NA-M, Ismail S. Association analysis of FTO gene polymorphisms and obesity risk among Egyptian children and adolescents. Genes Dis. 2017;4 (3):170-175. doi:10.1016/j.gendis.2017.06.002

43. Ohashi J, Naka I, Kimura R, et al. FTO polymorphisms in oceanic populations. J Hum Genet. 2007;52(12):1031-1035. doi:10.1007/ s10038-007-0198-2

44. Ramos AV, Bastos-Rodrigues L, Resende BA, et al. The contribution of FTO and UCP-1SNPs to extreme obesity, diabetes and cardiovascular risk in Brazilian individuals. BMC Med Genet. 2012;13(1):101. doi:10.1186/1471-2350-13-101

45. Sentinelli F, Incani M, Coccia F, et al. Association of FTO polymorphisms with early age of obesity in obese Italian subjects. Exp Diabetes Res. 2012;2012:1-7. doi:10.1155/2012/872176

46. Marcadenti A, Fuchs FD, Matte U, Sperb F, Moreira LB, Fuchs SC. Effects of FTO RS9939906 and MC4R RS17782313 on obesity, type 2 diabetes mellitus and blood pressure in patients with hypertension. Cardiovasc Diabetol. 2013;12(1):103. doi:10.1186/1475-2840-12-103

47. Gerken T, Girard CA, Tung YL, et al. The obesity-associated FTO gene encodes a 2-oxoglutarate - dependent nucleic acid demethylase. Science. 2007;318(5855):1469-1472. doi:10.1126/science.1151710. The

48. Fischer J, Koch L, Emmerling C, et al. Inactivation of the Fto gene protects from obesity. Nature. 2009;458(7240):894-898. doi:10.1038/ nature 07848 
49. Cecil JE, Tavendale R, Watt P, Hetherington MM, Palmer CNA. An obesity-associated FTO gene variant and increased energy intake in children. $N$ Engl $J$ Med. 2008;359(24):2558-2566. doi:10.1056/ NEJMoa0803839

50. Prakash J, Mittal B, Srivastava A, Awasthi S, Srivastava N. Association of FTO rs9939609 SNP with obesity and obesity- associated phenotypes in a North Indian population. Oman Med J. 2016;31(2):99-106. doi:10.5001/omj.2016.20

51. Gueorguiev M, Lecoeur C, Meyre D, et al. Association studies on ghrelin and ghrelin receptor gene polymorphisms with obesity. Obesity. 2009;17(4):745-754. doi:10.1038/oby.2008.589

52. Del Giudice EM, Santoro N, Cirillo G, et al. Molecular screening of the ghrelin gene in Italian obese children: the Leu72Met variant is associated with an earlier onset of obesity. Int $J$ Obes. 2004;28 (3):447. doi:10.1038/sj.ijo.0802572

53. Marks DL, Boucher N, Lanouette C, et al. Ala67Thr polymorphism in the Agouti-related peptide gene is associated with inherited leanness in humans. Am J Med Genet A. 2004;126(3):267-271. doi:10.1002/ajmg.a.20600

54. Li P, Tiwari HK, Lin W-Y, et al. Genetic association analysis of 30 genes related to obesity in a European American population. Int J Obes. 2014;38(5):724. doi:10.1038/ijo.2013.140

55. Vink T, Hinney A, van Elburg AA, et al. Association between an agouti-related protein gene polymorphism and anorexia nervosa. Mol Psychiatry. 2001;6(3):325. doi:10.1038/sj.mp.4000854

56. Argyropoulos G, Rankinen T, Neufeld DR, et al. A polymorphism in the human agouti-related protein is associated with late-onset obesity. J Clin Endocrinol Metab. 2002;87(9):4198-4202. doi:10.1210/jc.2002-011834

57. Van Rossum CTM, Pijl H, Adan RAH, Hoebee B, Seidell JC Polymorphisms in the NPY and AGRP genes and body fatness in Dutch adults. Int J Obes. 2006;30(10):1522. doi:10.1038/sj.ijo.0803314

58. Bray MS, Boerwinkle E, Hanis CL. Sequence variation within the neuropeptide Y gene and obesity in Mexican Americans. Obes Res. 2000;8(3):219-226. doi:10.1038/oby.2000.25

59. Srivastava A, Mittal B, Prakash J, Srivastava P, Srivastava N. Analysis of MC4R rs17782313, POMC rs1042571, APOE-Hha1 and AGRP rs3412352 genetic variants with susceptibility to obesity risk in North Indians. Ann Hum Biol. 2016;43(3):285-288. doi: $10.3109 / 03014460.2015 .1061597$
60. Loos RJF, Lindgren CM, Li S, et al. Common variants near MC4R are associated with fat mass, weight and risk of obesity. Nat Genet. 2008;40(6):768-775. doi:10.1038/ng.140

61. Xi B, Chandak GR, Shen Y, Wang Q, Zhou D. Association between common polymorphism near the MC4R gene and obesity risk: a systematic review and meta-analysis. PLoS One. 2012;7(9): e45731. doi:10.1371/journal.pone.0045731

62. Hester JM, Wing MR, Li J, et al. Implication of European-derived adiposity loci in African Americans. Int J Obes. 2012;36(3):465-473. doi:10.1038/ijo.2011.131

63. Grant SFA, Bradfield JP, Zhang H, et al. Investigation of the locus near MC4R with childhood obesity in Americans of European and African ancestry. Obesity. 2009;17(7):1461-1465. doi:10.1038/ oby. 2009.53

64. Han X, Luo Y, Zhang X, et al. Rs4074134 near BDNF gene is associated with type 2 diabetes mellitus in Chinese Han population independently of body mass index. PLoS One. 2013;8(2):e56898. doi:10.1371/journal.pone.0056898

65. Beckers S, Zegers D, de Freitas F, Mertens IL, Van Gaal LF, Van Hul W. Association study of MC4R with complex obesity and replication of the rs17782313 association signal. Mol Genet Metab. 2011;103(1):71-75. doi:10.1016/j.ymgme.2011. 01.007

66. Thorleifsson G, Walters GB, Gudbjartsson DF, et al. Genome-wide association yields new sequence variants at seven loci that associate with measures of obesity. Nat Genet. 2009;41(1):18. doi:10.1038/ ng. 274

67. Vitolo E, Santini E, Seghieri M, et al. Heterozygosity for the rs696217 SNP in the preproghrelin gene predicts weight loss after bariatric surgery in severely obese individuals. Obes Surg. 2017;27 (4):961-967. doi:10.1007/s11695-016-2387-6

68. Reuter CP, Rosane De Moura Valim A, Gaya AR, et al. FTO polymorphism, cardiorespiratory fitness, and obesity in Brazilian youth. Am J Hum Biol. 2016;28(3):381-386. doi:10.1002/ ajhb. 22798 


\section{Supplementary materials}

\section{PCR procedure for NPY polymorphism}

The region was amplified using custom designed primers (forward: 5'-GCGGCGAGGAAGCTCCATAA-3'; reverse: 5'-CCTAGACAGACGGGTCGTAG-3'). PCR reactions $(25 \mu \mathrm{l})$ consisted of 20-50 ng of DNA, 1 unit of Taq DNA polymerase (Biotools B\&M Labs. S.A, Madrid, Spain), 0.2 $\mathrm{mmol} / \mathrm{L}$ of each dNTP, $2 \mathrm{mmol} / \mathrm{L} \mathrm{MgCl}_{2}$ and 0.3 pmoles of each primer. The thermocycling condition started with an initial denaturation at $95^{\circ} \mathrm{C}$ for $10 \mathrm{~min}$, followed by 30 cycles of $94{ }^{\circ} \mathrm{C}$ for $1 \mathrm{~min}$; $60^{\circ} \mathrm{C}$ for $1 \mathrm{~min} ; 72^{\circ} \mathrm{C}$ for $1 \mathrm{~min}$; and a final extension step of $72{ }^{\circ} \mathrm{C}$ for $10 \mathrm{~min}$. The $159 \mathrm{bp}$ amplified fragment of $N P Y$ gene was analyzed on a $15 \%$ polyacrylamide gel.

Table SI Phenotypic characteristics of study population

\begin{tabular}{|c|c|c|c|c|c|c|c|}
\hline Parameters & $\mathbf{n}$ & All & $\mathbf{n}$ & Control & $\mathbf{n}$ & Case & $P^{*}$ \\
\hline $\begin{array}{l}\text { Age (years) } \\
\text { Gender (female/male) } \\
\text { Female } \\
\text { Male }\end{array}$ & 490 & $\begin{array}{l}36.0(27.0 ; 45.0) \\
358(76.1) \\
132(26.9)\end{array}$ & 192 & $\begin{array}{l}29.0(24.0 ; 27.0) \\
117(60.9) \\
75(39.1)\end{array}$ & 298 & $\begin{array}{l}40.0(31.0 ; 48.0) \\
241(80.9) \\
57(19.1)\end{array}$ & $\begin{array}{l}<0.001 \\
<0.001\end{array}$ \\
\hline $\begin{array}{l}\text { Race/skin color } \\
\text { White } \\
\text { Brown } \\
\text { Black }\end{array}$ & 489 & $\begin{array}{l}231(47.2) \\
169(34.6) \\
89(18.2)\end{array}$ & 191 & $\begin{array}{l}128(67.0) \\
49(25.7) \\
14(7.3)\end{array}$ & 298 & $\begin{array}{l}103(34.6) \\
120(40.3) \\
75(25.1)\end{array}$ & $<0.001$ \\
\hline $\begin{array}{l}\text { Marital status } \\
\text { Single } \\
\text { Married/cohabiting } \\
\text { Separated/divorced } \\
\text { Widower }\end{array}$ & 488 & $\begin{array}{l}220(45.1) \\
213(43.6) \\
34(7.0) \\
21(4.3)\end{array}$ & 192 & $\begin{array}{l}117(6 \mid .0) \\
64(33.3) \\
4(2.1) \\
7(3.6)\end{array}$ & 296 & $\begin{array}{l}103(34.8) \\
149(50.3) \\
30(10.2) \\
14(4.7)\end{array}$ & $<0.001$ \\
\hline $\begin{array}{l}\text { Smoking status } \\
\text { Already smoked } \\
\text { Never smoked }\end{array}$ & 483 & $\begin{array}{l}56(9.4) \\
427(90.6)\end{array}$ & 191 & $\begin{array}{l}\text { I8 (I3.0) } \\
\text { I73 (87.0) }\end{array}$ & 292 & $\begin{array}{l}38(\mathrm{II} .6) \\
254(88.4)\end{array}$ & 0.228 \\
\hline $\begin{array}{l}\text { Physical activity practice } \\
\text { Yes } \\
\text { No }\end{array}$ & 487 & $\begin{array}{l}155(31.8) \\
332(68.2)\end{array}$ & 192 & $\begin{array}{l}99(51.6) \\
93(48.4)\end{array}$ & 295 & $\begin{array}{l}56(19.0) \\
239(81.0)\end{array}$ & $<0.001$ \\
\hline $\begin{array}{l}\text { Type } 2 \text { Diabetes } \\
\text { Yes } \\
\text { No }\end{array}$ & 484 & $\begin{array}{l}59(12.2) \\
425(87.8)\end{array}$ & 192 & $\begin{array}{l}0(0.0) \\
192(100)\end{array}$ & 292 & $\begin{array}{l}59(20.2) \\
233(79.8)\end{array}$ & $<0.001$ \\
\hline $\begin{array}{l}\text { Hypertension } \\
\text { Yes } \\
\text { No }\end{array}$ & 490 & $\begin{array}{l}217(44.3) \\
273(55.7)\end{array}$ & 192 & $\begin{array}{l}9(4.7) \\
183(95.3)\end{array}$ & 298 & $\begin{array}{l}208(69.8) \\
90(30.2)\end{array}$ & $<0.001$ \\
\hline $\begin{array}{l}\text { Weight }(\mathrm{kg}) \\
\text { Height }(\mathrm{m}) \\
\text { BMI }\left(\mathrm{kg} / \mathrm{m}^{2}\right) \\
\text { Waist circumference }(\mathrm{cm}) \\
\text { Hip circumference }(\mathrm{cm}) \\
\text { WHR } \\
\text { BAI } \\
\text { Inverted BMI } \\
\text { Waist to height ratio } \\
\text { Waist to weight ratio } \\
\text { Glucose }(\mathrm{mg} / \mathrm{dL}) \\
\text { Total cholesterol }(\mathrm{mg} / \mathrm{dL})\end{array}$ & $\begin{array}{l}490 \\
490 \\
490 \\
488 \\
488 \\
488 \\
488 \\
490 \\
488 \\
488 \\
385 \\
423 \\
\end{array}$ & $\begin{array}{l}\text { I05.I }(67 ; 132.3) \\
\text { I.65 }(1.59 ; 1.72) \\
40.0(23.4 ; 48.8) \\
120.5(80.0 ; 139.9) \\
128.0(99.5 ; 145.4) \\
0.91(0.84 ; 0.98) \\
41.8(28.1 ; 51.6) \\
24.9(20.4 ; 42.7) \\
0.70(0.50 ; 0.90) \\
1.10(1.00 ; 1.30) \\
93.0(87.0 ; 102.0) \\
186.0(160.0 ; 216.0)\end{array}$ & $\begin{array}{l}192 \\
192 \\
192 \\
192 \\
192 \\
192 \\
192 \\
192 \\
192 \\
192 \\
176 \\
184\end{array}$ & $\begin{array}{l}63.0(57.0 ; 70.0) \\
1.68(1.61 ; 1.74) \\
22.8(21.1 ; 23.9) \\
81.0(75.0 ; 85.5) \\
98.0(93.0 ; 101.4) \\
0.83(0.78 ; 0.89) \\
26.9(24.1 ; 29.6) \\
43.8(41.8 ; 47.4) \\
0.5(0.4 ; 0.5) \\
1.30(1.20 ; 1.40) \\
89.0(84.0 ; 95.0) \\
178.5(156.0 ; 200.0)\end{array}$ & $\begin{array}{l}298 \\
298 \\
298 \\
296 \\
296 \\
296 \\
296 \\
298 \\
296 \\
296 \\
209 \\
239\end{array}$ & $\begin{array}{l}126.3(109.5 ; 144.2) \\
1.63(1.58 ; 1.69) \\
46.8(41.8 ; 52.8) \\
136.0(125.0 ; 147.0) \\
141.2(131.1 ; 152.7) \\
0.96(0.90 ; 1.00) \\
49.5(44.0 ; 56.0) \\
21.35(18.9 ; 23.9) \\
0.80(0.80 ; 0.90) \\
1.10(1.00 ; 1.10) \\
97.0(90.0 ; 110.0) \\
193.0(166.0 ; 224.0)\end{array}$ & $\begin{array}{l}<0.001 \\
<0.001 \\
<0.001 \\
<0.001 \\
<0.001 \\
<0.001 \\
<0.001 \\
<0.001 \\
<0.001 \\
<0.001 \\
<0.001 \\
<0.001\end{array}$ \\
\hline
\end{tabular}

(Continued) 
Table SI (Continued).

\begin{tabular}{|l|l|l|l|l|l|l|l|}
\hline Parameters & $\mathbf{n}$ & All & $\mathbf{n}$ & Control & $\mathbf{n}$ & Case \\
\hline HDL cholesterol (mg/dL) & 423 & $51.0(43.0 ; 61.0)$ & 184 & $59.0(48.0 ; 69.0)$ & 239 & $47.0(41.0 ; 53.0)$ & $<0.00 I$ \\
LDL cholesterol (mg/dL) & 416 & $110.0(91.0 ; 135.0)$ & 179 & $102.0(86.0 ; 123.0)$ & 233 & $117.0(95.0 ; 143.0)$ & $<0.001$ \\
Triglycerides (mg/dL) & 423 & $102.0(74.0 ; 139.0)$ & 184 & $77.0(61.0 ; 101.7)$ & 239 & $125.0(96.0 ; 168.0)$ & $<0.001$ \\
Hemoglobin (\%) & 340 & $5.3(4.9 ; 5.9)$ & 165 & $5.1(4.8 ; 5.4)$ & 175 & $5.8(5.1 ; 6.3)$ & $<0.001$ \\
CRP (mg/dL) & 336 & $0.42(0.12 ; 1.09)$ & 164 & $0.13(0.08 ; 0.28)$ & 172 & $1.00(0.55 ; 1.59)$ & $<0.001$ \\
SBP (mm Hg) & 345 & $121.0(111.0 ; 133.0)$ & 178 & $118.0(109.7 ; 125.2)$ & 167 & $130.0(117.0 ; 76.0)$ & $<0.001$ \\
DBP (mm Hg) & 345 & $80.0(70.5 ; 89.0)$ & 178 & $76.0(68.0 ; 82.0)$ & 167 & $85.0(76.0 ; 92.0)$ & $<0.001$ \\
\hline
\end{tabular}

Notes: Data are presented as median values (interquartile range $25-75 \%$ ) for quantitative traits and $\mathrm{n}$ (\%) for qualitative traits. Data were analyzed by Mann-Whitney Test (for non-normally distributed continuous variables) or $\chi 2$ test (for categorical variables). $P *$-value for differences between severely obese and normal-weight subjects. Abbreviations: BMI, Body Mass Index; WHR, Waist-hip ratio; BAI, Body Adipose Index; SBP, Systolic blood pressure; DBP, Diastolic blood pressure; HDL cholesterol, High-density lipoprotein-cholesterol; LDL cholesterol, Low-density lipoprotein-cholesterol; CRP, C-reactive protein. 


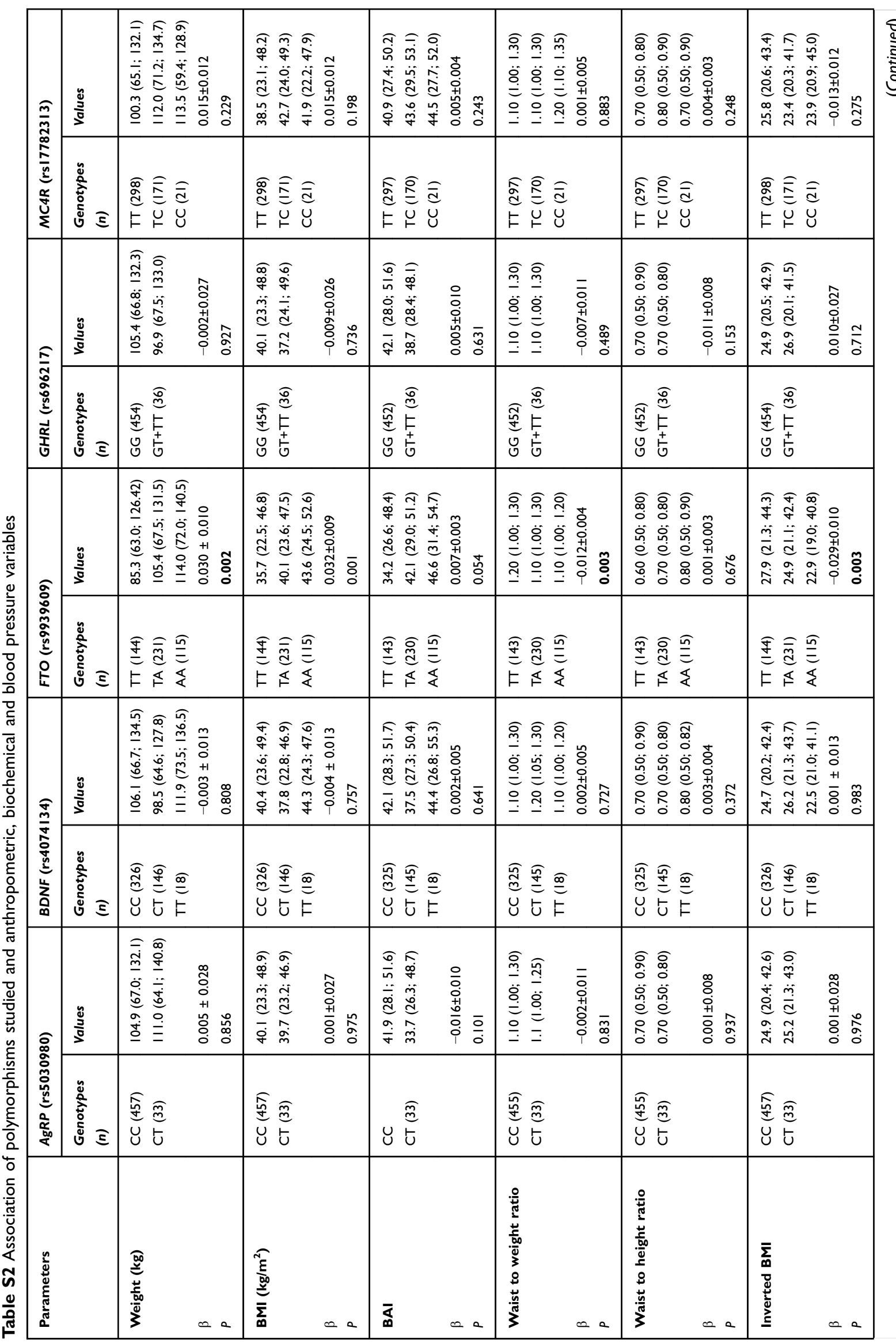




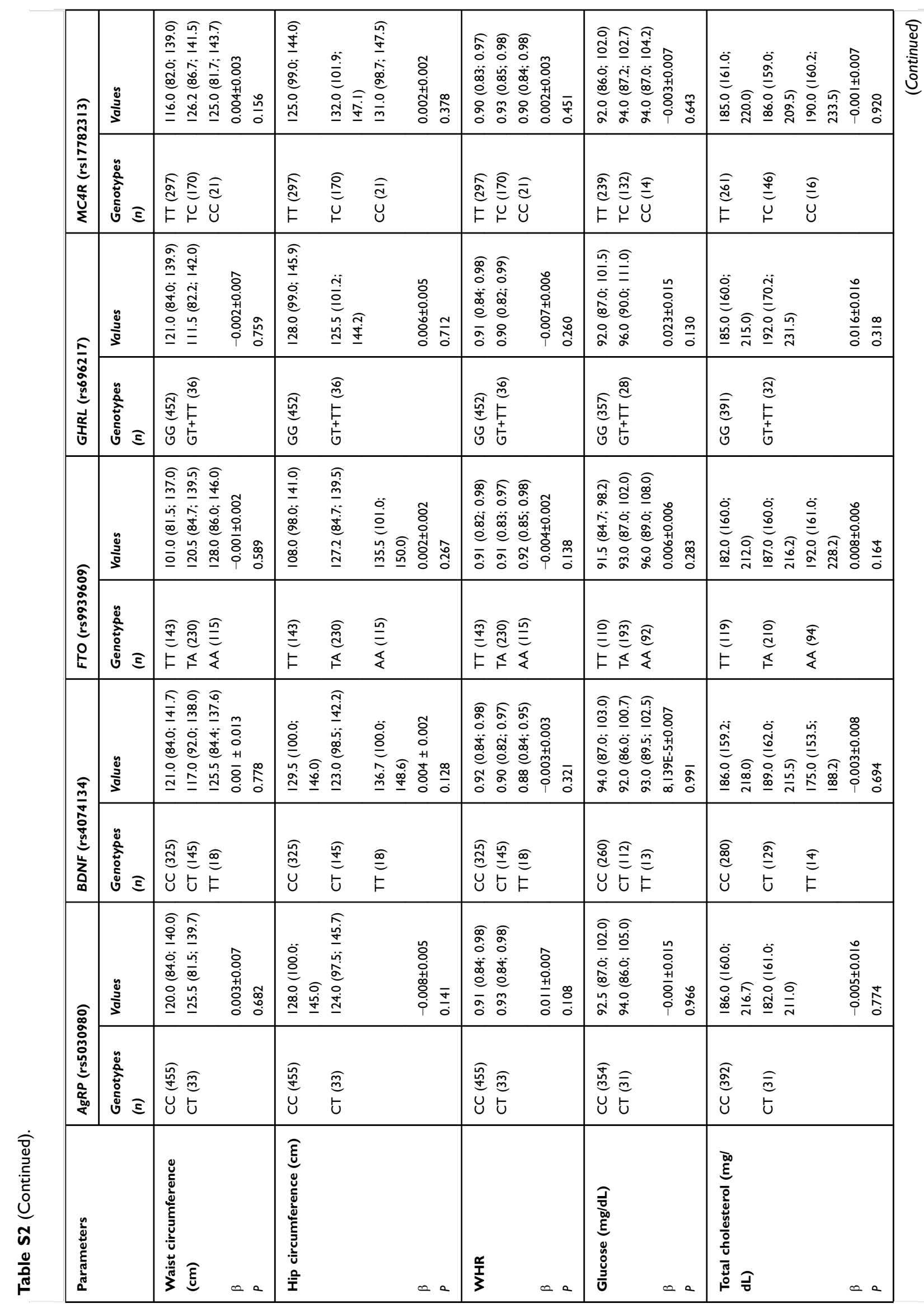




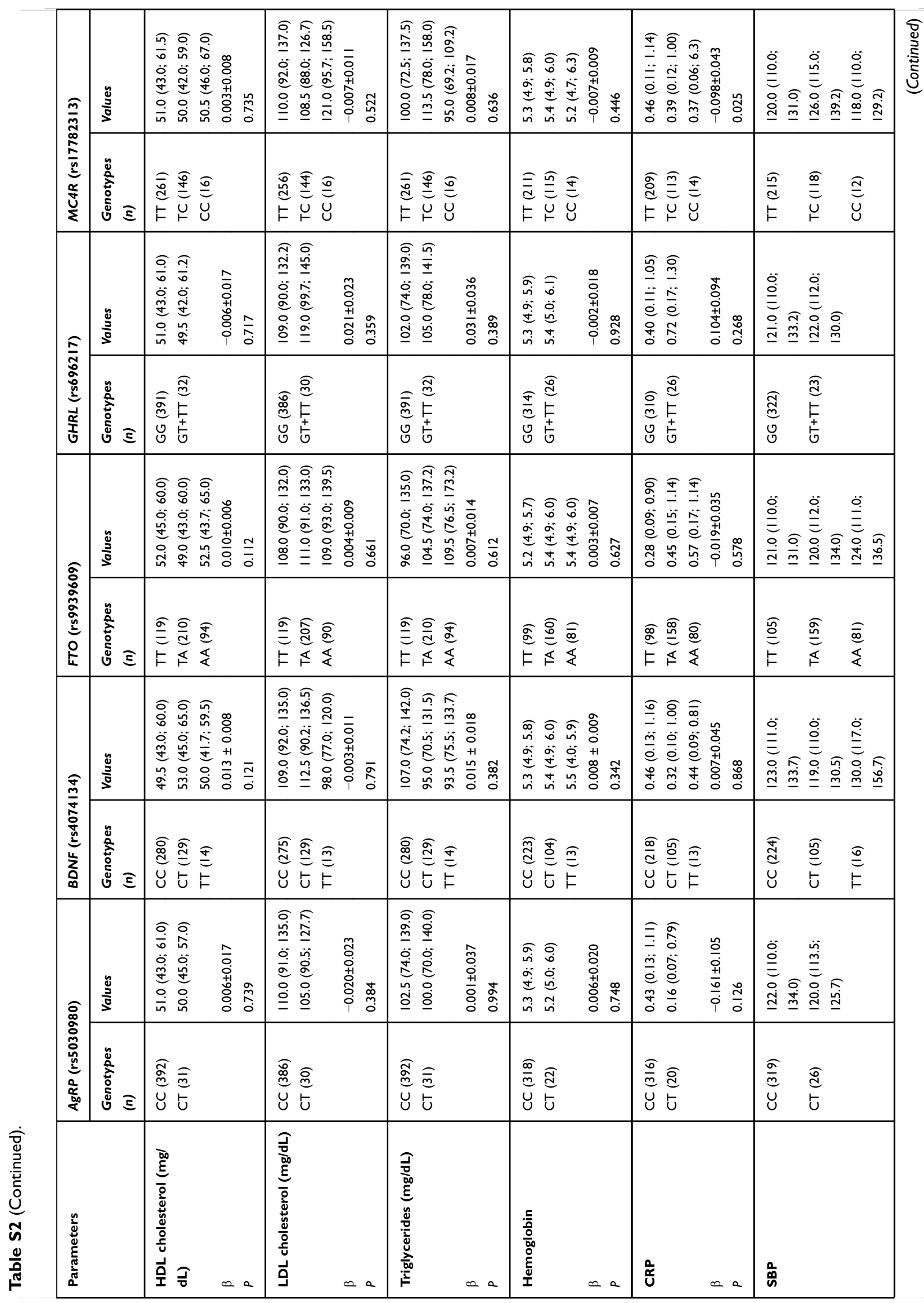




\begin{tabular}{|c|c|c|c|}
\hline \multirow{4}{*}{ 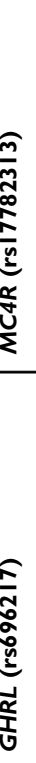 } & $\stackrel{\check{\Xi}}{\overline{5}}$ & $\begin{array}{l}\text { o } \\
\text { ơ } \\
\text { †1 } \\
\text { 荢 } \\
0 \\
0\end{array}$ & 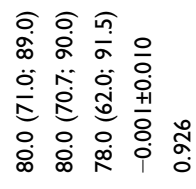 \\
\hline & פ & & 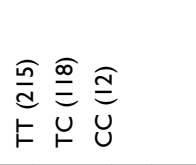 \\
\hline & 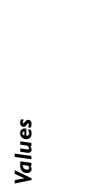 & 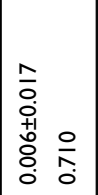 & 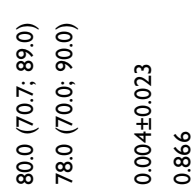 \\
\hline & 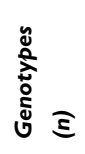 & & 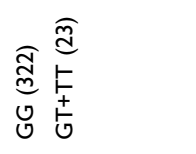 \\
\hline \multirow{2}{*}{ 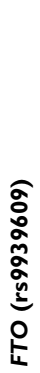 } & 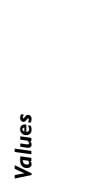 & 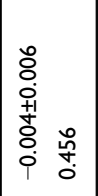 & 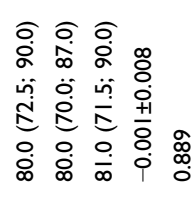 \\
\hline & 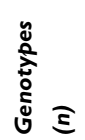 & & 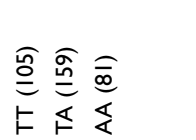 \\
\hline \multirow{2}{*}{ 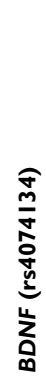 } & $\frac{\tilde{\Xi}}{\bar{\Xi}}$ & 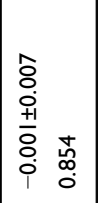 & 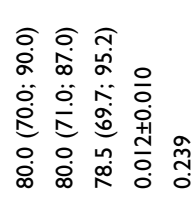 \\
\hline & 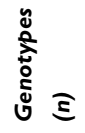 & & 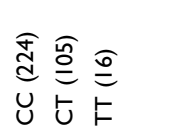 \\
\hline \multirow{2}{*}{ 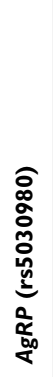 } & 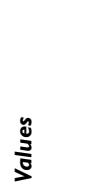 & 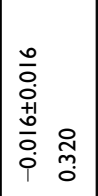 & 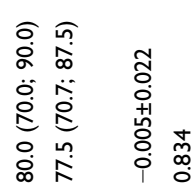 \\
\hline & 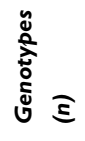 & & 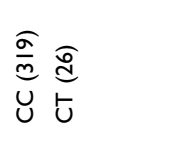 \\
\hline 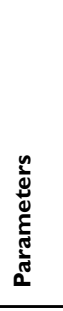 & & $\infty a$ & $\infty a$ \\
\hline
\end{tabular}




\section{Publish your work in this journal}

Diabetes, Metabolic Syndrome and Obesity: Targets and Therapy is an international, peer-reviewed open-access journal committed to the rapid publication of the latest laboratory and clinical findings in the fields of diabetes, metabolic syndrome and obesity research. Original research, review, case reports, hypothesis formation, expert opinion and commentaries are all considered for publication. The manuscript management system is completely online and includes a very quick and fair peer-review system, which is all easy to use. Visit http://www.dovepress.com/testimonials.php to read real quotes from published authors.

Submit your manuscript here: https://www.dovepress.com/diabetes-metabolic-syndrome-and-obesity-targets-and-therapy-journal 